\title{
Grip strength after forearm cooling in healthy subjects
}

\author{
Força de preensão palmar após resfriamento \\ do antebraço em indivíduos saudáveis
}

\author{
Pedro Henrique Reis Rabelo ${ }^{[a]}$, Kárenn Klycia Pereira Botelho ${ }^{[b]}$, Franassis Barbosa de Oliveira ${ }^{[a, c]^{*}}$ \\ [a] Universidade Estadual de Goiás (UEG), Goiânia, GO, Brazil \\ [b] Universidade Estadual de Goiás (UEG), Itaberaí, GO, Brazil \\ [c] Universidade de Brasília (UnB), Brasília, DF, Brazil
}

Abstract

Introduction: Muscle strength has shown different responses to the cooling of neuromuscular tissue and its behavior is still unclear. Objective: To verify the behavior of maximum grip strength before and after forearm cooling. Methods: The cooling intervention consisted of immersing the forearm up to the elbow in water cooled to $10^{\circ} \mathrm{C}$. Grip strength was assessed using a dynamometer prior to cooling, immediately after immersion, and at 5, 10 and 30 minutes of forearm exposure to ambient temperature (recovery phase) concomitantly to measurement of skin surface temperature. The sample consisted of 30 healthy individuals. Results: Grip strength decreased significantly $(\mathrm{p}<0.05)$ between the period prior to cooling and all the time intervals following immersion in ice water. There was also a gradual increase in grip strength during the recovery phase, with significant differences $(\mathrm{p}<0.05)$ between the mean immediately after immersion and means at 5, 15 and 30 minutes after exposure to ambient temperature. Conclusion: The results indicate that immersion in ice water $\left(10^{\circ} \mathrm{C}\right)$ for 15 minutes significantly reduced $(\mathrm{p}<0.05)$ grip strength for up to 30 minutes after forearm cooling. Strength also recovered progressively after removal of the cold stimulus. Further research is needed to obtain definitive results regarding the effects of cooling on muscle strength in healthy individuals.

Keywords: Hand Strength. Cryotherapy. Physical Therapy Specialty.

*PHRR: BS, e-mail: phrr9@hotmail.com KKPB: undergrad, e-mail: karenn_klycia@hotmail.com

FBO: PhD, e-mail: franassis_oliveira@yahoo.com.br 


\section{Resumo}

Introdução: A força muscular tem apresentado respostas controversas ao resfriamento dos tecidos neuromusculares e seu comportamento ainda não foi esclarecido. Objetivo: Verificar o comportamento da força de preensão palmar máxima antes e após o resfriamento do antebraço. Métodos: A intervenção de resfriamento consistiu na imersão do antebraço até o nível do cotovelo em água gelada a $10^{\circ} \mathrm{C}$. A força foi avaliada por dinamometria de preensão palmar antes da aplicação de frio, imediatamente após imersão e em 5, 15 e 30 minutos de exposição do antebraço à temperatura ambiente (fase de recuperação) concomitantemente à aferição da temperatura superficial da pele. A amostra foi composta por 30 indivíduos saudáveis. Resultados: A força de preensão palmar diminuiu significativamente $(p<0,05)$ entre o período anterior ao resfriamento e todos os períodos que sucederam à imersão em água gelada. A força de preensão palmar apresentou ainda aumento progressivo durante a fase de recuperação, com diferenças significativas $(p<0,05)$ entre a média do momento imediato ao fim da imersão e as médias dos momentos de 5, 15 e 30 minutos de exposição à temperatura ambiente. Conclusão: Os resultados indicaram que a imersão em água gelada a $10^{\circ} \mathrm{C}$ por 15 minutos diminuiu significativamente $(p<0,05)$ a força de preensão palmar por até 30 minutos após o resfriamento do antebraço. A força apresentou ainda capacidade progressiva de recuperação após a retirada do estímulo frio. Novas pesquisas devem ser realizadas para a apresentação de resultados definitivos sobre os efeitos do frio na força muscular de indivíduos saudáveis.

Palavras-chave: Força da Mão. Crioterapia. Fisioterapia

\section{Introduction}

Rehabilitation is part of the routine of high performance athletes, but is also essential for individuals who are not physically fit and exposed to trauma and stress. Understanding the healing process is a priority in physical rehabilitation; physical and chemical mechanisms that affect hemodynamics are triggered at different stages. However, the exacerbation of certain bodily responses may not be beneficial to rehabilitation and should be controlled (1).

The inflammatory response is the body's (typically local) reaction to an irritant. Its occurrence is beneficial and necessary for tissue regeneration, defending it against harmful factors and promoting the continuation of mechanisms needed for anabolism and catabolism, which contribute to tissue repair. However, certain signs and symptoms mediated by inflammation, such as pain and edema, can compromise rehabilitation and delay an individual's return to normal function (2).

A number of therapeutic tools are recommended to control undesirable inflammatory signs; however, Guirro and Guirro (3) highlight that cryotherapy has advantages in terms of its low cost, easy application of the technique, and a wide range of actions. Cryotherapy or cold therapy involves the application of substances at a temperature considerably below that of the skin, removing heat energy in order to lower its temperature (2).

The expected local and immediate physiological effects of cold application are decreased skin temperature, blood flow, local metabolism (2 - 4) and nerve conduction velocity $(2,5,6)$.

When a structure is submitted to cooling, different types of tissue are indirectly involved, each capable of exhibiting distinct physiology in accordance with the environment in which it is assessed, as is the case with low temperatures. In order to validate this information, studies have compared the effect of different types of cold on muscle tissue (7 - 9), nerve fibers (6), joints $(10)$ and skin $(5,11)$.

According to Oksa (12), cooling causing inadequate muscle performance by affecting muscle components and functional properties, as well as their electrical activity.

In this respect, Guirro and Guirro (3) analyzed muscle physiology after cooling, emphasizing that frequent exposure to cold may be a risk factor for musculoskeletal disorders, since changes in electrical activity after cooling may be related to inefficient motor control and reduced muscle performance.

Despite good evidence indicating decreased conduction velocity in muscle nerve fibers $(2,5,6)$ and 
several studies investigating the behavior of isometric (13-16) and isokinetic muscle strength $(17,18)$, the ability of cooling to alter muscle strength is still considered inconclusive (19), with consistent recommendations for further research on the issue (6, 13-15).

According to Sasaki et al. (20), grip strength (GS) assessments are easy to administer and require lowcost, easily transportable equipment. When applied correctly, these tests have shown good validity and reliability (21). Moreira et al. (22) argue that this measure is an extremely effective outpatient procedure and an important parameter in evaluating hand function.

Among the instruments developed for GS measurement, the Jamar ${ }^{\circledR}$ dynamometer enjoys the greatest clinical acceptance, has been proven to be effective, and has been used for data collection in different scientific studies (21).

The response of muscle strength to cooling is the object of this study, specifically maximum grip strength and surface temperature of the skin after forearm cooling. The aim was to describe muscle strength behavior following immersion in ice water.

\section{Methods}

The convenience sample consisted of 30 healthy individuals of both sexes, 15 men and 15 women, selected among students at the ESEFFEGO University Unit of Universidade Estadual de Goiás.

The study was conducted in accordance with human research guidelines and regulations (resolution 196/1996 of the National Health Council) and was approved by the Research Ethics Committee of the Office of the President of Research and Graduate Studies/UFG under protocol no 110/2011. No research funding was received.

First, subjects completed a semi-structured questionnaire that provided information pertaining to inclusion or exclusion from the study. For the purpose of sample characterization, the questionnaire also established the numerical identification, age, sex, dominant upper limb, weight and height of participants, and included a table to control the variables during data collection (grip strength, skin temperature, water temperature).

Subjects were healthy individuals (no reported neural, musculoskeletal, rheumatic or skin diseases); aged between 18 and 30 years $(23,24)$; capable of performing maximum grip strength maneuvers with the dominant limb and understanding the study characteristics, including risks.

Exclusion criteria were any contraindication for cryotherapy (2); body mass index (BMI) below 18 and above $24.99(6,15)$; fractures, upper limb or back surgery in the last two years (15) and unwillingness to participate or collaborate with the study.

The following instruments were used for data collection: a 15 L, 35 centimeter deep plastic basin; two stools; thermoneutral water; crushed ice; 36-liter cooler; Jamar ${ }^{\circledR}$ hydraulic dynamometer that measures strength in kilograms $(\mathrm{Kg})$ with two parallel straps (one fixed and the other adjustable to five different positions), duly calibrated for the study and used to assess isometric GS; high accuracy $\left(0.1^{\circ}\right)$ Minipa ${ }^{\circledR}$ MT-350 infrared digital thermometer $\left({ }^{\circ} \mathrm{C}\right)$ used to measure the surface temperature of the skin (STS); anthropometric scale with a capacity up 150 $\mathrm{kg}$; stadiometer with a measuring capacity up to 2.20 meters; digital stopwatch; anthropometric tape measure; permanent marker; and a digital camera.

The researchers advised subjects of the date and time of data collection and instructed them not to exercise or consume stimulants such as chocolate, energy drinks or substances containing alcohol or caffeine on the day of the intervention $(5,6)$.

The study was conducted at the ESEFFEGO University Unit of Universidade Estadual de Goiás. Data were collected in an air conditioned room $\left(23^{\circ} \mathrm{C}\right)(14$, 15 ) at the same time of day (between 8 a.m. and 12 p.m.) to ensure that body temperature was not significantly affected by circadian cycles (6). In their first 15 minutes in the room, the time required for acclimatization, subjects were assessed by the researchers in terms of their weight, height, and the possible presence of skin disorders. Next, participants' dominant forearm was measured from the medial epicondyle to the head of the ulna, placing a mark in the middle and on the outer edge of the medial epicondyle (Figure 1). The middle was calculated according to the length of each forearm and the marking was made midway (forearm length divided by two) along the imaginary line between the medial epicondyle and head of the ulna. Also in this initial period, subjects were instructed on the correct procedure and posture for the intervention. They were also shown how to handle the dynamometer in order to adapt and practice their grip on the device, which should remain the same throughout the procedure. 
Figure 1 - Forearm markings.

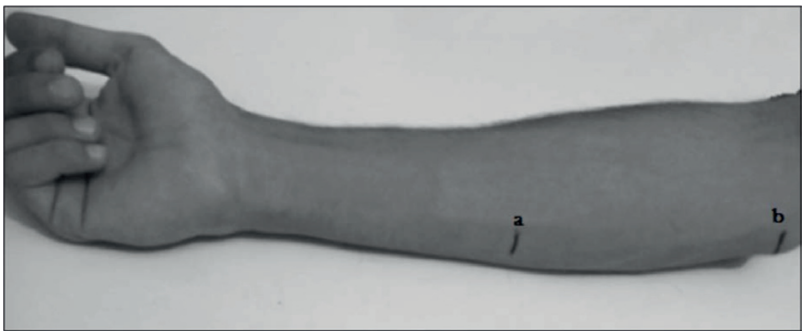

Note: (a) middle of the forearm, (b) outer edge of the medial epicondyle. Source: author's personal archive, 2011.

For each GS assessment, participants were seated on a stool with the shoulder of their dominant arm adducted, elbow flexed to $90^{\circ}$, forearm in a neutral position, wrist extension varying between $0^{\circ}$ and $30^{\circ}$ and ulnar deviation from $0^{\circ}$ to $15^{\circ}$. The assessor was positioned in front of the subjects, stabilizing the instrument. The handle of the Jamar ${ }^{\circledR}$ dynamometer was set to position two for the tests (21). Three grip measurements were taken to calculate the average value for the dominant hand in each assessment, with a 30-second rest between measurements. The volunteers performed the grip during expiration, without executing the Valsalva maneuver, and were verbally encouraged during the test using the command "squeeze hard!". GS was assessed by dynamometry before cooling and during the recovery phase (15 minutes after immersion in water cooled to $10{ }^{\circ} \mathrm{C}$ and in the first 5, 15 and 30 minutes of post-cooling exposure to ambient temperature).

STS was checked before each measurement, with the thermometer positioned over the middle marking of the forearm about two centimeters away from the skin (6).

The cryotherapy intervention used for cooling was immersion (cold water), considered by Chersterton et al. (5) and Herrera et al. (6) as the most effective means of reducing the conduction velocity of peripheral nerves and keeping it low after cooling. While still in the position used for strength assessment, the subjects' dominant forearm was immersed in the plastic container filled with cold water $\left(10^{\circ} \mathrm{C}\right)(2,25)$ up to the mark on the medial epicondyle.

Temperature was analyzed before and after immersions. Immersion time was based on the study by Malone et al. (26), who advocate a period of 15 minutes to safely cool neuromuscular components without compromising their integrity. The order of events was as follows: strength and temperature assessments, cooling, and a further four strength and temperature evaluations at predetermined times (immediately after immersion and at 5, 5 and 30 minutes of exposure to ambient temperature).

The data from these assessments were recorded on individual evaluation charts for each participant. The statistical program used was SPSS (Statistical Package for the Social Science Statistics for Windows) version 15.0. The Shapiro-Wilk test was applied and the sample was considered normal, with a p-value of 0.008. One-way ANOVA was used to compare the means, with a significance level of $5 \%(\mathrm{p}<0.05)$.

\section{Results}

The sample consisted of 30 healthy individuals, 15 men and 15 women. The mean \pm standard deviation (SD) of age was 20.67 years ( \pm 1.53 years), weight $63.73 \mathrm{Kg}( \pm 9.74 \mathrm{Kg})$, height $1.72 \mathrm{~m}( \pm 0.09$ $\mathrm{m})$ and BMI $21.16 \mathrm{Kg} / \mathrm{m}^{2}\left( \pm 1.77 \mathrm{Kg} / \mathrm{m}^{2}\right)$. Of the 30 participants, the upper right arm was dominant in 28 (frequency of 93.3\%) and the upper left in 2 (frequency of $6.7 \%$ ). Figures 2 and 3 show the means and standard deviations (SD) for the grip strength (GS) and surface temperature of the skin (STS) at the different collection times. The moment prior to cooling was denominated Pre (0), immediately after cooling Post (0), and 5, 15 and 30 minutes after the intervention Post (5), Post (15), and Post (30), respectively.

Figure 2 - Variation in mean grip strength in the different assessments.

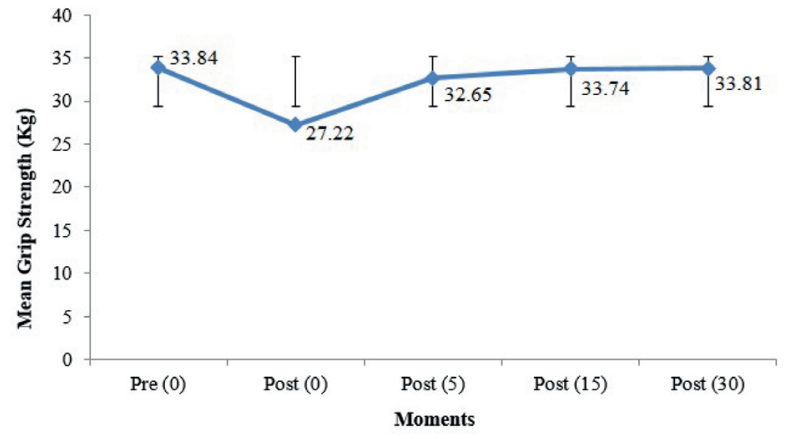

Note: Moments (minutes), Grip Strength (Kg). Source: the author, 2011. 
Figure 3 - Variation in mean skin temperature in the different assessments.

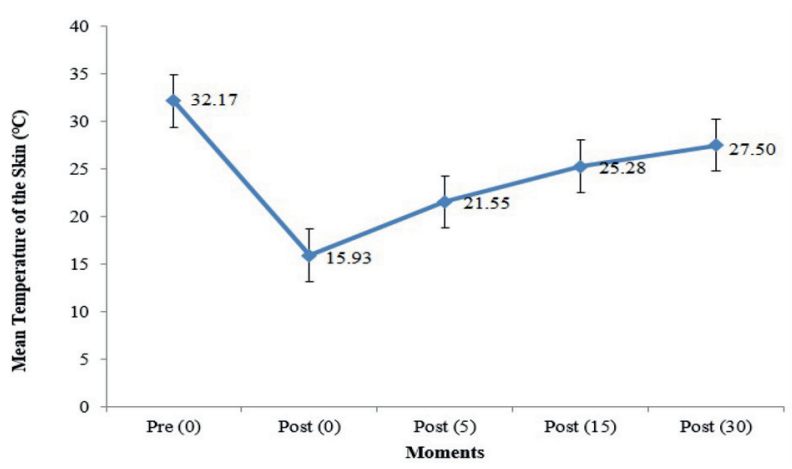

Note: Moments (minutes), Surface Temperature $\left({ }^{\circ} \mathrm{C}\right)$. Source: the author, 2011.

Table 1 shows the mean difference percentages for GS between Pre (0) and Post (0), Post (5), Post (15) and Post (30) assessments.

Table 1 - GS comparison $(\mathrm{Kg})$ before and after cooling indicating the mean percentage difference

\begin{tabular}{ccc}
\hline Moment & Moment & $\begin{array}{r}\text { Mean } \\
\text { (\%) }\end{array}$ \\
\hline Pre (0) & Post (0) & -19.57 \\
Pre (0) & Post (5) & -3.52 \\
Pre (0) & Post (15) & -0.30 \\
Pre (0) & Post (30) & -0.10 \\
\hline
\end{tabular}

Note: mean difference - percentages (\%).Source: the author, 2011.

The paired difference between means and significance level at the different GS assessment times are displayed in Table 2. A significant difference $(\mathrm{p}<0.05)$ was observed for pairs between Pre (0) and Post (0), Post (5), Post (15) and Post (30); Post (0) and Post (5), Post (15) and Post (30); and Post (15) and Post (30).

Table 2 - Paired difference in means and significance level for GS $(\mathrm{Kg})$ at the different assessment times

(To be continued)

\begin{tabular}{cccc}
\hline Moment & Moment & $\begin{array}{c}\text { Mean } \\
\text { Difference }\end{array}$ & $\begin{array}{c}\text { Significance } \\
(\mathbf{p}<\mathbf{0 . 0 5})\end{array}$ \\
\hline Pre (0) & Post (0) & 6.62 & $0.048^{*}$
\end{tabular}

$\begin{array}{lccc}\text { Pre (0) } & \text { Post (5) } & 1.19 & 0.003^{\star} \\ \text { Pre (0) } & \text { Post (15) } & 0.10 & 0.011^{\star} \\ \text { Pre (0) } & \text { Post (30) } & 0.03 & 0.046^{\star} \\ \text { Post (0) } & \text { Post (5) } & -5.43 & 0.028^{\star} \\ \text { Post (0) } & \text { Post (15) } & -6.52 & 0.000^{\star} \\ \text { Post (0) } & \text { Post (30) } & -6.58 & 0.003^{\star} \\ \text { Post (5) } & \text { Post (15) } & -1.09 & 0.664 \\ \text { Post (5) } & \text { Post (30) } & -1.15 & 0.702 \\ \text { Post (15) } & \text { Post (30) } & -0.07 & 0.000^{\star}\end{array}$

Note: $(*)$ significant difference between means $(\mathrm{p}<$ 0.05). Source: the author, 2011.

Mean GS at Post (0), Post (5), Post (15) and Post (30) declined significantly $(\mathrm{p}<0.05)$ when compared to the mean for Pre (0), while means at Post (5), Post (15) and Post (30) increased significantly ( $p<0.05)$ compared to the mean at Post (0) (Table 2). These results indicate a significant decrease $(p<0.05)$ in strength after cooling compared to strength measured by dynamometer prior to the intervention. In addition, strength increased over time, since the mean difference at Post $(0)$ was the highest $(\mathrm{p}<0.05)$ among the recovery phases (Post (0), (5), (15) and (30) when compared to Pre (0) (Table 2).

In relation to Pre (0), GS declined by $19.57 \%$ at Post (0), 3.52\% at Post (5), $0.30 \%$ at Post (15) and $0.10 \%$ at Post (30) (Table 1).

These results show that isometric muscle strength assessed by grip strength dynamometry declined immediately after cooling and continued to do so for up to 30 minutes, but gradually improved over time (Figure 2).

STS behaved similarly to GS after cooling (Figures 2 and 3), indicating a direct relationship between reduced temperature and decreased strength. In the recovery phase (Post (0), (5), (15) and (30), a concomitant increase was observed in STS and GS, suggesting a direct association between the variables during this period.

\section{Discussion}

The relationship between reduced temperature and the ability to generate strength is controversial in the literature. Several studies $(14,15,18,27)$ recommend temperature reduction while others $(13$, $16,17)$ report no change in strength. These investigations also stand out in terms of cooling protocols, voluntary isometric maximal $(14,15,27)$ and 
submaximal $(13,16)$ strength assessments, as well as isokinetic evaluation $(17,18)$.

The decline in strength reported in the present study was almost $20 \%$ in absolute values after 15 minutes of cooling. Douris et al. (14) observed a strength reduction of approximately $25 \%$ for a period of up to 20 minutes' immersion in cold water. Cornwall (27) reported a decrease in strength of up to $33 \%$ after 20 minutes of cooling, while Pereira (15) recorded a decline of over $43 \%$ after 30 minutes of cold application. As in the present study, these authors $(14,15$, 27 ) analyzed the performance of isometric muscle strength, reporting significant differences between measurements before and after cooling.

With regard to the recovery period, the findings of Douris et al. (14) were similar to those presented here, with significant differences in strength values up to 15 minutes after the intervention. By contrast, although post-cooling absolute values for isometric strength did not reach those recorded prior to cooling, Pereira (15) found no significant differences in mean strength between 5 and 60 minutes after cooling. Cornwall (27) did not assess strength behavior during the recovery phase.

Analysis of these results suggests that caution is needed when recommending exercises that require maximum (100\%) muscle strength immediately after using resources that cool tissue.

In order to study muscle efficiency and sensory motor control of voluntary movement at low temperature, Coulange et al. (13) evaluated maximal and submaximal (60\%) voluntary contraction responses after cooling in 10 professional divers from the French Navy. The authors concluded that complete immersion of the body in cold water did not affect maximal or submaximal voluntary contraction. Despite the marked differences between these results and those presented here, it is important to note that participants in the aforementioned study were submitted to a different assessment and immersion protocol, and were accustomed to diving. As such, they may have a unique response to immersion in cold water.

Rubley et al. (16) also studied submaximal isometric muscle strength and, similarly to Coulange et al. (13), found no significant differences after cooling by submersion of the forearm in cold water. The cooling protocol consisted of immersing the forearm in cold water $\left(10^{\circ} \mathrm{C}\right)$ for 15 minutes. No significant differences were observed in the ability to reach the submaximal values proposed for cooling when the cooled forearm was compared to control measures for the opposing limb.
Using a 30-minute cooling protocol on the legs of 22 individuals, Kimura et al. (17) evaluated potential changes in muscle strength for eccentric isokinetic plantar flexion. Subjects were assessed after immersion in water cooled to $10^{\circ} \mathrm{C}$ and compared against control conditions. The results showed no significant difference between conditions and the findings differed from those recorded here; however, methodological differences hampered result comparison.

The effects of cooling on concentric and eccentric muscle strength, measured via isokinetic testing, were also investigated by Ruiz et al. (18), who assessed the isokinetic strength of the quadriceps femoris muscle in a group of 19 young wrestlers. The muscle in question was cooled for 25 minutes using an ice pack, prompting a significant decline in strength compared to pre-application values. These results corroborate the findings of the present study, despite differences in cooling time and method, as well as the strength assessment technique.

The most widely studied explanation for reduced strength due to cooling is the decline in myoelectric activity caused by low tissue temperatures (3).

Knight (2) argues that decreased temperatures lead to an increase in the duration of potential action associated with a rise in latency after depolarization (refractory period). These factors reduce the number of fibers that may fire at a given time, thus reducing nerve conduction velocity (NCV). As such, there is a direct relationship between NCV and temperature decline, while the refractory period and duration of action potential are inversely proportional to impulse propagation speed (28). The range of potential action is related to the number of nerve fibers that respond to an effective electrical stimulus (6). Thus, the change in this condition after cooling appears to be linked to an increase (2) or blockade (6) in the electrical transmission threshold for nerve fibers more sensitive to cooling.

In a literature review, Oksa (12) reported that the biochemical reasons described for changes in muscle activity due to cooling are related to the reduced breakdown of ATP (triphosphate adenosine), delayed release of calcium by the sarcoplasmic reticulum and lower affinity of calcium for myosin, which interferes directly in the formation of cross-bridges needed for muscle contraction.

The contraindication of applying cryotherapy in conjunction with exercises that require maximum strength immediately after the cooling intervention 
depends on the assessment of the clinicians involved, since variables such as application time and the type of cooling and tissue involved directly influence the level of cooling and likely change in strength $(2,6,8)$. However, we believe that an absolute contraindication is not necessary provided precautions are taken. The results obtained in this study indicate a minimum time (5 minutes) for strength recovery, with a decline of less than $4 \%$ compared to initial values.

Three additional factors should be considered in regard to contraindications/precautions after using cryotherapy. The first is related to indication: the most common application of cryotherapy is in the acute rehabilitation phase (2), when maximum intensity exercises are not typically prescribed or well tolerated (29). The second pertains to the fact that submaximal intensity exercises seem to be unaffected by cooling. Coulange et al. (13) and Rubley et al. (16) study the effect of cold on submaximal exercises from 10 to $60 \%$ of total intensity and found no significant changes in strength. The third factor is that low intensity exercises immediately after cryotherapy have been described as capable of accelerating the recovery of parameters affected by the cold that can alter strength, such as intramuscular temperature (29) and nerve conduction velocity (30).

It is important to underscore that these exercises, in conjunction with cooling, may also lead to recovery of the desired therapeutic parameters, affecting nervous conduction velocity as a result of post-cryotherapy hypoalgesia, for example, (6).

In light of the above, the following precautions are suggested after cooling: in the event that exercise is recommended after skin cooling, submaximal level activity is preferable; should maximum intensity exercise be prescribed immediately after cooling, low intensity exercise should be performed beforehand for preparatory purposes.

\section{Conclusion}

The aim of this study was to analyze maximum grip strength after forearm cooling in healthy men and women. Although cold applications have been consistently investigated for therapeutic benefits, this study analyzed only the controversial relationship between local cooling and strength.

The cooling time, conditions and technique used (immersion in cold water at $10^{\circ} \mathrm{C}$ for 15 minutes) were considered efficient in reducing grip strength. This decline was significant $(\mathrm{p}<0.05)$ between assessment prior to cooling and all the evaluations conducted after cold application, indicating that, despite progressive recovery, strength remained diminished even after 30 minutes' rest at room temperature.

The gradual increase in GS during the recovery phase is evident in the significant differences $(p<0.05)$ between mean strength immediately after cooling and at 5, 15 and 30 minutes' exposure to room temperature.

This study presented clinically relevant results, but was limited in terms of investigating only isometric strength (grip) based on controlling the surface temperature (skin). The actual temperature of neurosmuscular tissue cannot be estimated and assessments that include electroneuromyography will likely provide a clearer picture of what takes place in contractile tissue after cooling. Another clear limitation is the study of healthy individuals, a population that does not typically require cryotherapy. Thus, further study is needed to encompass different clinical cooling protocols and include populations other than those analyzed to date, in addition to applying more accurate techniques to determine the effects of cold on muscle strength.

\section{References}

1. Prentice WW, Voight ML. Técnicas em reabilitação musculoesquelética. 1st ed. Porto Alegre (Brazil): Artmed; 2003.

2. Knigth KL. Crioterapia no tratamento das lesões esportivas. 1st ed. São Paulo: Manole; 2000.

3. Guirro E, Guirro R. Fisioterapia dermato funcional. 3rd ed. São Paulo: Manole; 2002. Portuguese.

4. Myer JW, Myer KA, Measom GJ, Fellingham GW, Evers SL. Muscle temperature is affected by overlying adipose when cryotherapy is administred. J Athl Train. 2001;36(1):32-6.

5. Chesterton LS, Foster NE, Ross L. Skin temperature response to cryotherapy. Arch Phys Med Rehabil. 2002;83:543-9.

6. Herrera E, Sandoval MC, Camargo DM, Salvini TF. Motor and sensory nerve conduction are affected differently by ice pack, ice massage and cold water immersion. Phys Ther. 2010;90(4):1-10. 
7. Dykstra JH, Hill HM, Miller MG, Cheatham CC, Michael TJ, Baker RJ. Comparisons of cubed ice, crushed ice, and wetted ice on intramuscular and surface temperature changes. J Athl Train. 2009;44(2):136-41.

8. Merrick MA, Jutte LS, Smith ME. Cold modalities with different thermodynamic properties produce different surface and intramuscular temperatures. J Athl Train. 2003;38(1):28-33.

9. Tomchuck D, Rubley MD, Holcomb WR, Guadagnoli M, Tarno JM. The magnitude of tissue cooling during cryotherapy with varied types of compression. J Athl Train. 2010;45(3):230-7.

10. Warren TA, MCcarty EC, Richardson AL, Michener T, Spindler KP. Intra-articular knee temperature changes: ice versus cryotherapy device. Am J Sports Med. 2004;32:441-5.

11. Kennet J, Hardaker N, Hobbs S, Selfe J. Colling efficiency of 4 common cryotherapeutic agents. J Athl Train. 2007;42(3):343-8.

12. Oksa J. Neuromuscular performance limitations in cold. Int J Circumpolar Health. 2002;61:154-62.

13. Coulange M, Hug F, Kipson N, Robinet C, Desruelle AV, Melin B, et al. Consequences of prolonged total body immersion in cold water on muscle performance and EMG activity. Eur J Appl Physiol. 2006;452(1):91-101.

14. Douris P, MCkenna R, Madigan K, Cesarski B, Costiera R, Lu M. Recovery of maximal isometric grip strength following cold immersion. J Strength Cond Res. 2003;17(3):509-13.

15. Pereira LG. Avaliação da atividade eletromiográfica e da força isométrica máxima do tibial anterior após aplicação de crioterapia [master's thesis]. São Paulo: Universidade do Vale do Paraíba; 2008. Portuguese.

16. Rubley MD, Denegar CR, Buckley WE, Newell KM. Cryotherapy, sensation and isometric-force variability. J Athl Train. 2003;38(2):113-9.

17. Kimura IF, Gulick DT, Thompson GT. The effect of cryotherapy on excentric plantar flexion peak torque and endurance. J Athl Train. 1997;32(2):124-6.

18. Ruiz DH, Myer JW, Durant E, Fellingham GW. Cryotherapy and sequential exercise bouts following cryotherapy on concentric and eccentric strength in the quadriceps. J Athl Train. 1993;28(4):320-3.
19. Richendollar ML, Darby LA, Brown TM. Ice bag application, active warm-up, and 3 measures of maximal functional performance. J Athl Train. 2006;41(4):364-70.

20. Sasaki H, Kasagi F, Yamada M, Fujita S. Grip strength predicts causespecific mortality in middle-aged and elderly persons. Am J Med. 2007;120:337-42.

21. Figueiredo IM, Sampaio RF, Mancini MC, Silva FC. Teste de força de preensão utilizando o dinamômetro Jamar. Acta Fisiatr. 2007;14(2):104-10.

22. Moreira D, Alvárez RRA, Godoy JR, Cambraia AN. Abordagem sobre preensão palmar utilizando o dinamômetro Jamar: uma revisão de literatura. Rev Bras Ci e Mov. 2003;11(2):95-9.

23. Luna-Heredia E, Martin-Peña G, Ruiz-Galiana J.Handgrip dynamometry in healthy adults. Clin Nutr. 2005;24(2):250-8.

24. Schlussel MM, Anjos LA, Vasconcellos MTL, Kac G. Reference values of handgrip dynamometry of healthy adults: a population-based study. Clin Nutr. 2008;27(4):601-7.

25. Bleakley C, MCdonough S, Macauley D. Use of ice in treatment of acute soft-tissue injury. A systematic review and randomized controlled trials. Am J Sports Med. 2004;32(1):251-61.

26. Malone TR, Engelhardt DL, Kirkpatrick JS, Bassett FH. Nerve injury in athletes caused by cryotherapy. J Athl Train. 1992;27(3):235-7.

27. Cornwall MW. Effect of temperature on muscle force and rate of muscle force production in men and women. J Orthop Sport Phys Ther. 1994;20(2):74-80.

28. Dioszeghy P, Stalberg E. Changes in motor and sensory nerve conduction parameters with temperature in normal and diseased nerve. Electroencephalogr Clin Neurophysiol. 1992;85(4):229-35.

29. Myer JW, Measom GJ, Fellingham GW. Exercise after cryotherapy greatly enhances intramuscular rewarming. J Athl Train. 2000;35(4):412-6.

30. Herrera E, Sandoval MC, Camargo DM, Salvini TF. Efeito do exercício pós-crioterapia na recuperação da condução nervosa. Rev Bras Fisioter. 2010;15(3):233-40.

Received in 08/06/2014 Recebido em 06/08/2014

Approved in 11/12/2015 Aprovado em 12/11/2015 